\title{
Rethinking the problem: Outcomes or sustainability?
}

\section{RODNEY MUTH}

Division of Administrative Leadership and Policy Studies, University of Colorado at Denver and Health Sciences Center, Campus Box 106, P.O. Box 173364, Denver, CO 80217-3364, U.S.A.;

E-mail: rodney.muth@cudenver.edu

\section{Observational standpoint}

As a policy scientist, Professor Pielke is problem-oriented and has articulated concerns that I share (Muth, 1996, 1999b, 2000a). However, his perspective is pessimistic; mine is optimistic. Although I had read Lasswell's (1936) Politics: Who Gets What, When, How in college during the 1960s, I understood neither its broad implications nor its connection to the vast array of his work on politics, problem solving, political psychology, and content analysis and propaganda. Such topics were among the many that Lasswell explored initially as a student during the 1920s and later as a professor at the University of Chicago and Yale University (Muth, 1990). In addition, I was fortunate to work with Lasswell directly when he advised programs supported by the Mershon Center at Ohio State University. These programs, led by Richard Snyder (Muth, 1999a) during the early- to mid-1970s, developed around the policy sciences, particularly the decision seminar (Lasswell, 1960, 1966, 1971a; Muth and Slonaker, 1976).

The result is that I became a largely self-taught, continuously aspiring policy scientist (Muth, 2000b) who has led the "dual life" referenced by Pielke (2004). I have maintained standing in my employing "community," educational leadership, while from time to time dabbling in the policy sciences, trying to apply some of its principles and techniques both explicitly (Muth, 1987) and less so (e.g., Doll and Muth, 1995; Farnham and Muth, 1989; Gier, Murphy, and Muth, 2002) to problems that face educators and policy makers concerned about education and its outcomes.

Even though I am an aspiring policy scientist, I have developed my vantage point because of my short association with Lasswell and my interest in his concept of the decision seminar (e.g., Bolland and Muth, 1984; Muth, 1987). Following his death in 1978, I searched Lasswell's corpus to discover everything about the decision seminar and its variants (Muth, Finley, and Muth, 1990). I also was a founding member of the Policy Sciences Summer Institute in 1982 (later renamed Policy Sciences Annual Institute), co-edited a short-lived policy sciences newsletter in the early 1980s, and am currently a member of the Executive Council of the Society for the Policy Sciences and the International Editorial Board of the Policy Sciences.

Through such connections, I have been associated with the policy sciences "movement" for more than 30 years. I use the concepts and practices as I can but still consider 
myself an outsider looking in: never formally trained and only able to incorporate my learning partially into my "real" work. I am devoted, however, to the essential promises and purposes of the policy sciences, to the need for its enlightened perspectives and practice of pursuing common interest to ensure the widest possible shaping and sharing of human dignity (see, for example, Lasswell and McDougal, 1992).

\section{The problem as Pielke sees it}

As Pielke outlines the problem, the issue is the sustainability of the policy sciences. He maintains at the outset of his argument that sustainability depends on faculty producing

graduate students with mastery of the distinctive approach of the policy sciences and an ability to teach that knowledge [italics added] to subsequent generations of scholars and teachers. The alternative is that the tradition gradually fades into history as a consequence of inevitable attrition (p. 4).

Based on this assumption, Pielke poses this question: "if sustainability is desired (itself an open question), how might the policy sciences overcome those factors that militate against sustainability?" He then argues that three external factors (reverence for prediction, axiology of science, and politicization) and three internal factors (faculty and degrees, course materials and pedagogy, and identity) mitigate sustainability. These challenges must be overcome if the policy sciences are to survive the loss of second-generation policy scientists, a problem faced in most areas with aging experts (DeLong, 2004).

Although Pielke suggests that the desirability of sustainability is "an open question," he then outlines the importance of sustainability, details how external and internal factors might be allayed, and proposes a way to do this. His solution is for the policy sciences to mimic other disciplines, a perspective which in and of itself could rigidify the policy sciences and thus doom them to the very obscurity - perhaps eventually only a historical footnote - that Pielke and others (cf. Ascher and Brunner, 1995) dread.

\section{An alternative conception of the problem}

Perhaps because I long have been concerned with the issue of carrying forward the banner of the policy sciences, Pielke's apprehension is of particular moment for me. Sustainability, however, may be only a secondary or tertiary problem. Much as Pielke suggests, though, the question may be formed best as "sustainability for what?" That is, why sustain the policy sciences if they actually are "losing ground" (Ascher and Brunner, 1995, Section I.A., $\llbracket 2,6$ ) to long-standing disciplines that have mastered the criteria that Pielke outlines and thereby offer nothing more than traditional disciplines provide? 
Put simply, if policy scientists have built a better mousetrap, the world should beat a path their door. Unfortunately, such success is not always the reward, even for a superior mousetrap. Ascendant positions are hard to topple, as Ascher and Brunner (1995) note, and well-established perspectives, even if narrow, misguided, or incorrect, often are controlling, mostly because they have been reified by years of revered assumptions, arcane languages, active boundary maintenance, political utility, or delphic oracles.

Therefore, the problem may be one of impact rather than sustainability. Consider, for example, the matter of outcomes. Considered directly, do the policy sciences produce better policy? Do these policies adequately address the fullness of the problem, focus on the common good, and increase the positive distribution of human dignity? While a definitive answer to this question is beyond the scope of this response, it surely should be part of any ongoing discussion of the future of the policy sciences. Results do count, after all. Further, they suggest different considerations than do hypotheses about perpetuation. What, for example, makes the policy sciences distinctive when compared to other ways of improving policy processes, their outcomes, and their consequences? And what strategies might those who care about better outcomes and consequences develop to impact and, perhaps, heighten credibility (the outstanding mousetrap) and sustainability (the path beaten to the policy sciences by policy developers and users)?

\section{Distinctiveness}

The policy sciences should be preserved and enhanced, because, as Pielke notes, Lasswell (1971b) positioned the policy sciences to be problem-oriented, multi-method, and contextual. They seek to solve problems such that common interest is achieved, and they focus explicitly on improving human dignity for the greatest number possible. Maintaining the core value of human dignity clearly makes the policy sciences normative, a principle to which policy scientists adhere and traditional disciplines often object. Effective practitioners of the policy sciences understand that all policy issues are value based and hold their solution in the common interest as a grounding tenet. This position is eschewed by most social and other sciences as inappropriate, even though every matter studied requires a choice among competing interests and values. Thus, the value-based policy sciences deliberately choose to bring all of the sciences to bear on a policy problem, selecting all appropriate methods of observation to understand the problem provisionally within its larger context, moving back and forth, from part to whole, and through the past and present to the future, seeking creative, integrative solutions that support common interests and the expansion of human dignity. To exploit such distinctiveness in a world generally obeisant to certainty requires nontraditional approaches, a future orientation, and, in short, the audacity to strive for positive outcomes.

\section{Strategies}

Strategies to address these ends have been proposed by Pielke who advocates traditionalizing as the most likely means to achieve sustainability. In contrast, my multi- 
pronged strategy includes building upon current trends and focusing directly on the goal of increasing the impact of the policy sciences, thereby heightening their profile and credibility. Doing so requires continuing, problem-focused, collaborative policy interventions that prove themselves to be what the policy sciences claim: more thorough, more broadly and deeply developed, and more clearly focused on common interests and intent on increasing human dignity for all.

Given this starting point, policy scientists collaboratively and affirmatively could move to resolve problems of mutual interest, seeking preferred outcomes using the common language, frameworks, and purposes of the policy sciences. Unlike traditional disciplines which, within the norms of academe, value individual work that too often focuses on small, idiosyncratic specializations, the policy sciences address broad issues while seeking solutions to specific problems of practice that impede the achievement of common interests or the development of practices that enhance human dignity. Without attention to conceptions that unify and focus on improving policy outcomes, most strategies (e.g., discipline building or function enhancement) will have limited effect.

\section{A challenge}

The challenge is for small or large groups of policy scientists - joined by common interests, unifying conceptions, and preferred futures - to develop policy projects organized around mutual interests. Calls for action to stimulate such enterprise might be issued by the Society for the Policy Sciences. These collaborative projects could engage outsiders, drawing them in and providing them "on-the-job" training. Such experiences would capitalize on the current strengths of policy scientists, develop new ones, and build solutions that have broad but effective appeal. By exposing others to the values, frameworks, and outcomes of the policy sciences, the working cadre of policy scientists and perhaps the Society for the Policy Sciences could expand rapidly.

Resources among members of the Society are varied and great. Policy scientists are employed in many academic disciplines (the historical model), work in corporate or governmental settings, or act as independent consultants. They are lawyers, educators, and political, social, or natural scientists concerned about the environment, world order, power and authority, hunger and poverty, the development of democratic processes and nations, and many other arenas. Prompted by abundant policy problems awaiting solution and engaged by convergent foci, policy scientists as a body could target their energies, marshalling their necessarily broad range of capacities to meet the challenge of impact, credibility, and sustainability.

Harnessing such energies is almost easy when compared to what it would take to establish a new discipline in traditional settings, essentially clothing a wolf in sheep's attire and placing the wolves at extreme disadvantage over the long haul by threatening established disciplines in resource-poor times. But the interests of our third-generation colleagues, particularly those bound to the expectations of academe, need to be considered, so multiple approaches should be encouraged. Problem-focused projects, workshops, courses, and sections of the Policy Sciences Annual Institute should continue to identify, analyze, and report on issues that support and advance 
careers in amenable ways, and perhaps, lead to sustained, large-scale efforts at policy reform. Over time, the canons of academe can be satisfied, and junior partners will become senior.

\section{The learning enterprise}

In his focus on "teaching the policy sciences," Pielke takes a very traditional view of a very nontraditional approach. Traditional teaching develops one convert at a time, with little foreknowledge of who that might be, just as Pielke opines. The need, however, is to engage many aspirants in action learning (Morley, 1989; Stringer, 1996) and to involve them in hands-on, collaborative, and authentic change (Grabinger, Dunlap, and Duffield, 1997). Problem-focused seminars, workshops, and research projects could grow from efforts to identify problems of practice in areas that attract current policy scientists and also initiate others who simply want to find effective problem solutions.

Processes like these, capitalizing on getting something done, originally attracted me to Lasswell's work in the early 1970s. Using the decision seminar technique, we focused on improving educational outcomes for school children in some of the country's most problematic school districts at the time: Detroit, St. Louis, and San Francisco (Muth and Slonaker, 1976). Because knowledge is a social construct and learning is a social process (Bruffee, 1993), collaborative learning can effectively focus on mutually attractive and beneficial projects (see Lasswell's [1971b, p. 16] maximization postulate). Collaboration strengthens learners' commitment (Harasim, 1990), helps them develop critical thinking skills (Duffy, Dueber, and Hawley, 1998), and enhances their cognitive development (Sharan, 1980), all vital to understanding and using the frameworks and philosophy of the policy sciences. Besides, Lasswell was a student of Dewey's (1938) educational philosophy and its key orientation: most people learn best by doing.

\section{Seeking common ground}

Pielke's sustainability plan would convert the policy sciences to a traditional discipline, but the policy sciences are unlike the traditional disciplines which isolate themselves to maintain boundaries and manageable foci of attention. Rather, the policy sciences are integrative, demanding both multiple methods (ways of observing problems) and disciplines (ways of understanding problems) because no single discipline can address adequately the complexity of today's or tomorrow's policy problems. For example, is sociology (my academic background) able to explain fully the genesis and appeal of terroristic approaches to the redistribution of values? Can psychology alone explain why some children have difficulty succeeding in today's schools? Can anthropology alone resolve the seemingly intractable conflicts in the United States over abortion or other value-laden issues? For that matter, is any substantial modern problem susceptible to restricted theories or methodologies?

Instead of beginning with disciplinary divisions, starting with the nature of the problem that one confronts or wants to understand should determine ways to observe 
it. As Lasswell often pointed out, we learn from the past (trends) so that we can work on present problems (goals, trends, conditions, projections, alternatives) to affect the future (outcomes, effects). Indeed, most problems today are immensely complex and require multiple frames and methods to reach solutions of comparable breadth, depth, and sophistication. Because few problems are discrete enough to be easily amenable to a single, narrowly drawn perspective, a productive role for the policy sciences at the outset of this transformative process assuredly rests on their ability to conceptualize problems broadly and to harmonize and focus disparate perspectives. And herein lies our optimistic and forward-looking challenge of impact, credibility, and sustainability.

\section{References}

Ascher, W. and R. D. Brunner (1995). 'Society for the policy sciences,' retrieved September 1, 2004, from http://www.policysciences.org/workpaper1.htm.

Bolland, J. and R. Muth (1984). 'The decision seminar: A new approach to urban problem solving,' Knowledge: Creation, Diffusion, Utilization 6: 75-88.

Bruffee, K. (1993). Collaborative Learning: Higher Education, Interdependence and the Authority of Knowledge. Baltimore: Johns Hopkins University Press.

DeLong, D. W. (2004). Lost Knowledge: Confronting the Threat of an Aging Workforce. New York: Oxford University Press.

Dewey, J. (1938). Experience and Education. New York: Macmillan.

Doll, B. and R. Muth (1995, April). Psychiatric Disorders in Youth: A Policy Proposal. Paper presented at the Annual Meeting of the American Educational Research Association, San Francisco.

Duffy, T. M., W. Dueber and C. L. Hawley (1998). 'Critical thinking in a distributed environment,' in C. J. Bonk and K. King, eds., Electronic Collaborators: Researching the Discourse of Learner-Centered Technologies for Literacy, Apprenticeship and Discovery. Mahwah, NJ: Lawrence Erlbaum.

Farnham, J. and R. Muth (1989, March). Educational Policy Making in New York State. Paper presented at the Annual Meeting of the American Educational Research Association, San Francisco.

Gier, M. M.,. J. Murphy and R. Muth (2002, April). Using the Policy Delphi to Identify Stakeholder Values in Policy Development and Implementation. Paper presented at a special session on Value and Validity in Higher Education Research at the Annual Meeting of the American Educational Research Association, New Orleans.

Grabinger, S., J. C. Dunlap and J. A. Duffield (1997). 'Rich environments for active learning in action: Problem-based learning,' Alt-J 5(2): 5-17.

Harasim, L. M. (1990). 'Online education: An environment for collaboration and intellectual amplification,' in L. M. Harasim, ed., Online Education: Perspectives on a New Environment. New York: Praeger, pp. 39-67.

Lasswell, H. D. (1936). Politics: Who Gets What, When, How. New York: McGraw-Hill.

Lasswell, H. D. (1960). 'Technique of decision seminars,' Midwest Journal of Political Science 4: 213-236.

Lasswell, H. D. (1966). 'Decision seminars: The contextual use of audiovisual means in teaching, research, and consultation,' in R. L. Merritt and S. Rokkan, eds., Comparing Nations: The Use of Quantitative Data in Cross-National Research. New Haven, CT: Yale University Press, pp. 499-524.

Lasswell, H. D. (1971a). 'The continuing decision seminar as a technique of instruction,' Policy Sciences 2: $43-57$.

Lasswell, H. D. (1971b). A Pre-view of Policy Sciences. New York: American Elsevier.

Lasswell, H. D. and M. S. McDougal (1992). Jurisprudence for a Free Society: Studies in Law, Science, and Policy. New Haven, CT: New Haven Press; Dordrecht: Martinus Nijhoff.

Morley, D. (1989). 'Frameworks for organizational change: Towards action learning in global environments,' in S. Wright and D. Morley, eds., Learning Works: Searching for Organizational Futures. Toronto: ABL Group, Faculty of Environmental Studies, York University, pp. 163-190.

Muth, R. (1987). 'The decision seminar: A problem-solving technique for school administrators,' Planning and Changing 18: 45-60. 
Muth, R. (1990). 'Harold Dwight Lasswell: A biographical profile,' in R. Muth, M. Finley and M. Muth, Harold D. Lasswell: An Annotated Bibliography. New Haven, CT: New Haven Press; Dordrecht, The Netherlands: Kluwer Academic Publishers, pp. 1-49.

Muth, R. (1996, October). Teaching Policy Science: An Oxymoron? Paper presented at the Annual Policy Sciences Institute, New Haven, CT.

Muth, R. (1999a, February). Richard C. Snyder: Policy Scientist. Panel presentation on the Continuing Contributions of Richard C. Snyder at the 40th Annual Convention of the International Studies Association, Washington, DC.

Muth, R. (1999b, October). Clarifying What Policy Scientists Need to Know and be Able to Do. Paper presented at the Policy Sciences Annual Institute, New Haven, CT.

Muth, R. (2000a, October). Developing Policy Scientists: A National Agenda (Training leaders in the policy sciences). Paper presented at the Policy Sciences Annual Institute, New Haven, CT.

Muth, R. (2000b, October). Teaching One's Self: Seeking Understanding in the Policy Sciences. Paper presented at the Policy Sciences Annual Institute, New Haven, CT.

Muth, R., M. Finley and M. Muth (1990). Harold D. Lasswell: An Annotated Bibliography. New Haven, CT: New Haven Press; Dordrecht, The Netherlands: Kluwer Academic Publishers.

Muth, R. and L. Slonaker (1976, July). Toward a More Comprehensive Strategy for Strengthening Educational Leadership and Policymaking: A Design for Clinical Education, Research and Service. Columbus: Mershon Center, Ohio State University (USOE OEG 0-70-2108 [725]).

Pielke, R. A., Jr. (2004). 'What future for the policy sciences?' Policy Sciences (this issue).

Sharan, S. (1980). 'Cooperative learning in small groups: Recent methods and effects on achievement, attitudes and ethnic relations,' Review of Educational Research 50: 315-342.

Stringer, E. T. (1996). Action Research: A Handbook for Practitioners. Thousand Oaks, CA: Sage. 